\title{
Natural Topographical Concept of "Hulu-Teben" at Banjar Gunungsari Desa, Jatiluwih Tourist Destination Village
}

\author{
Wayan Parwata ${ }^{1}$, Nyoman Kaca ${ }^{2}$, Putu Pertamawati ${ }^{3}$ \\ \{iwayanpawarta01@gmail.com ${ }^{1}$,nyomankaca@yahoo.co.id ${ }^{2}$, pertama_483@yahoo.co.id $\left.{ }^{3}\right\}$ \\ The Lecturer of Engineering Faculty, Warmadewa University ${ }^{1}$ \\ The Lecturer of Agricultural Faculty, Warmadewa University ${ }^{2}$ \\ The Lecturer of Faculty of Economic, Warmadewa University ${ }^{3}$
}

\begin{abstract}
The concept of Hulu-Teben is a hierarchical space in Bali which is known as a sacred and profane space. This hierarchy has existed in Banjar Gunungsari Desa, Jatiluwih Village since the beginning of this village was formed. This area has been enthroned the World Cultural Heritage on $29^{\text {th }}$ of June 2012. As a village pattern structure, the Hulu-Teben concept needs preserving to maintain social and cultural structure of Jatiluwih Village. The analysis of land use, system of accessibility and use of space is carried out with community development program approach, which is expected to improve the standard of living for local community. There are several things expected from this research, such as, 1) residents' need to physical facility planning of public buildings $(18 \%)$; 2) village infrastructure $(20 \%)$; 3) Tourism supporting facilities $(25 \%)$; 4) art and cultural development (10\%) and preservation of subak system and irrigation infrastructure (27\%). From the management aspect: the role and residents involvement in management $(60 \%)$ and the government $(40 \%)$.
\end{abstract}

Keywords: Natural Topography, Hulu-Teben, social participation, and tourist destination.

\section{Introduction}

Jatiluwih Village is about $46 \mathrm{kms}$ from Denpasar City. This village located in in Penebel Sub-District, Tabanan Regency, has a very beautiful rural natural panorama and powerful traditional culture. Banjar Gunungsari Desa is part of the area of Jatiluwih Village. This Banjar located at an altitude of 700 meters above sea level, has an average rainfall of 2500 $\mathrm{mm} /$ year. The temperature ranges between $22^{\circ}-29^{\circ} \mathrm{C}$, so the air temperature around Banjar Gunungsari Desa is very cool. 


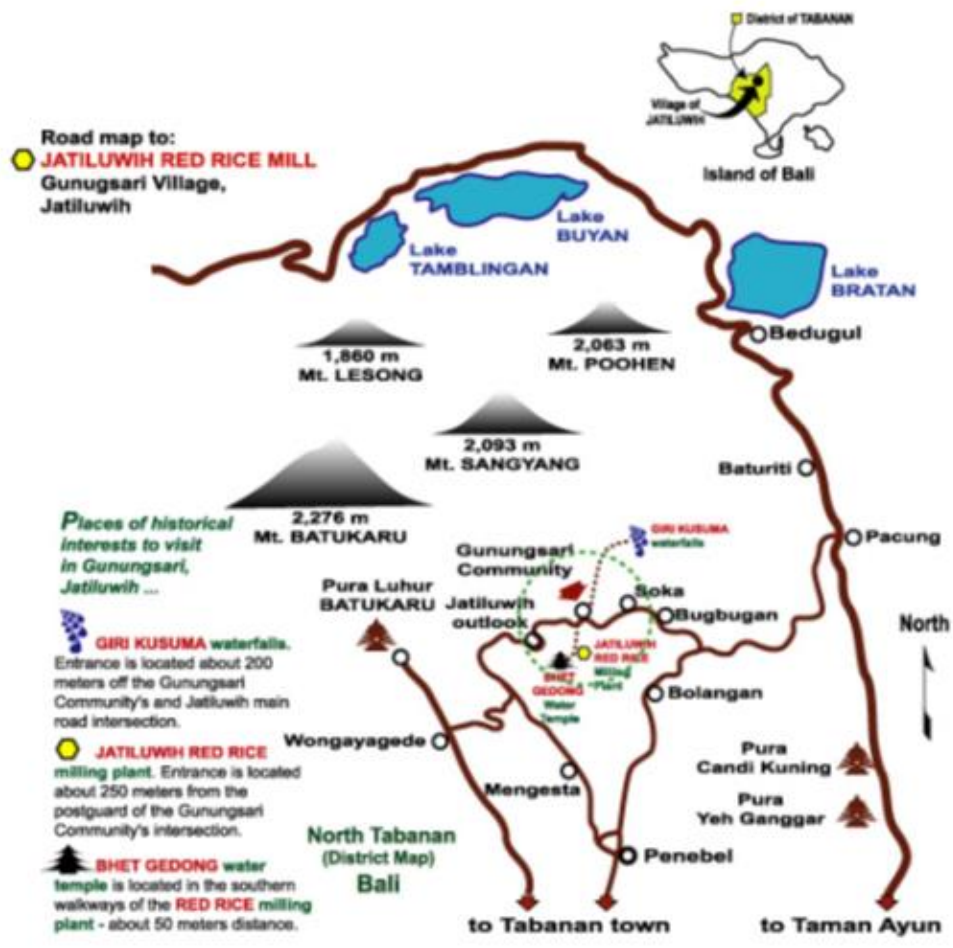

Fig. 1. Location of Banjar Gunungsari Desa, Jatiluwih Village Source: HeruTarjoto, 2014

The area of this banjar has natural topography that is clearly visible in the pattern of Hulu - Teben. Temples and spiritual facilities are located in the Main/North (Kaja) position (the highest area), while the residential area is under the sacred and graveyard (setra) area on the south side of the banjar (the lowest area).

Most of the villagers of Gunungsari Desa make a living as farmers. The stretch of rice fields for work is located at the back of their homes. In relation to the development of tourism, Banjar Gunungsari Desa also has experienced changes in spatial, social, economic and culture. Although there has been no significant change, the government and community must immediately anticipate this development.

The development of tourism that has reached Jatiluwih Village has become a challenge for the people of Jatiluwih and its surroundings area such as Banjar Gunungsari Desa. This area has become one of the targets for investment developers in tourism sector. Without serious and decisive management and control, both government, academics and community leaders will undoubtedly change sporadically like other regions in Bali. Moreover since 3 years ago, exactly $29^{\text {th }}$ of June 2012, Jatiluwih Village was awarded as a World Cultural Heritage area. Without strict efforts and regulations on the utilization of Jatiluwih area, this area tends to be eroded by the interests of groups or individuals. 


\section{Literature Review}

\subsection{Tourism and Spatial Arrangement in Bali}

Spatial arrangement with the concept of hulu-teben is a guideline of value system in achieving the goal of alignment between Bhuwana Agung and Bhuwana Alit where huluteben has an orientation, such as: (1) based on the axis of the earth, namely: direction of kajakelod (mountain and sea); (2) high-low direction (tegeh and lebah); and based on the Sun axis, namely; East-West (Sunrise and sunset). Value System are based on the earth axis (kaja/Mount-kelod/sea), provide the main values in the direction of kaja (mountain) and nista in the direction of kelod (sea), while based on the axis of the sun; the main value in the direction of sunrise and nista in the direction of sunset.

The layout of Traditional Balinese Architecture (TBA) that we receive now has a background or is based on the concept of "nobleness", meaning to respect ancestors in the form of the process of corpse burial, then pengabenan and mamukur or nyekah and finally the enshrining ceremony for Hyangdewa or dewapitara in Sanggah Kemulan (Ardana, 1982).

Ardana (1982) asserted that in addition to the belief in hulu-teben (top-down) displayed in the form of putting the direction of corpse towards a hill or mountain, this belief constitutes the belief of Balinese people at that time that their ancestral spirits were in altitude place or mountain. This concept (hulu-teben) is still valid in every village environment and housing planning in Bali. The pattern of orientation of traditional villages in Bali also still applies the Hulu-Teben concept.

The respect to the ancestors at that time continues to this day, many holy places are found in Bali which are aimed at honoring their ancestors. Such as, sanggah or pemerajan can be found in almost every yard of a house in Bali. The pattern also evolved from the sanggah, which is spread to the grandeur, the orphanage to the ancestry of his ancestors. The concept of Rwe Bhineda (hulu - teben, purusa - pradana), Hulu-Teben is two intimate poles where hulu has the main value while teben has the value of nista/dirty. While purusa (male) pradana (female) is the embryo of a life.

The concept of Tri Hita Karana has demonstrated various advantages and noble values that are universal and relevant to the environment and sustainable development. Tri Hita Karana implicitly contains the message that in managing natural resources including water resources wisely to preserve them, we are always grateful to God and always prioritize harmonious relations between humans, so the emergence of conflict can be anticipated. (Sutawan, 2004 in Wesnawa, 2010).

\subsection{Community-Based Tourism}

The beauty of tourist area at Banjar Gunungsari Desa is one of the tourism potentials that can be developed as a community-based tourism village. Tourism village is a form of tourism inhabited by a small group of tourists in or near traditional life or remote villages and studying village life and local environment (Inskeep, 1991).

Nuryanti (1992) defines a tourism village as a form of integration between attractions, accommodations, and supporting facilities that are presented in a structure of community life integrated with the prevailing procedures and traditions. According to Nuryanti, the most important components in a tourism village are: (1) accommodation: part of the residence of local residents or building units developed from the occupancy of local residents, (2) attractions: the entire daily life of local residents and the physical setting of the village 
location which may integrate tourists as active participants, such as dance, language, painting and other courses.

In relation to the development of tourist village having the concept of Hulu-Teben, Pearce (1995) defines it as a process emphasizing the importance of natural traditional concept and must be maintained to develop or advance the village. The traditional architectural value possessed by the physical location of the village should be preserved to complement and improve tourism facilities in meeting the needs of tourists.

Local communities play a very important role in the development of tourism village because the resources and uniqueness of traditions and culture inherent in the community are the main driving forces of tourism village activities. The success of developing a tourist village depends on the level of acceptance and support from the local community (Wearing, 2001). If it is viewed from the aspect of position, Wearing (2001) asserts that the local community has equal capacity as the government and private sector, so logically the results acquired from tourist attractions in a region must be equally shared between local communities, government and investors as one of the stakeholders in tourism development.

Therefore, in relation to the preservation of concept of "Hulu-Teben" at Banjar Gunungsari village, it is necessary to involve the community intensively. According to Timothy (1999) in Urmila Dewi (2013), it is emphasized that the importance to involve community in a decision making, namely, by accommodating the desires and goals of the community to maintain the authenticity of its territory and its ability to absorb tourism benefits.

\section{Research Methods}

The method applied is descriptive-qualitative, by focusing on the study of hulu-teban (top-down) concept as one of the traditional concepts supporting tourist attractions at Banjar Gunungsari Desa. The case study is restricted to Banjar Gunungsari Desa area, Jatiluwih Village. Data collection methods used are field surveys, in-depth interviews with community leaders, interviews with local residents and the government of Tabanan Regency in charge in spatial and social affairs as well as data collection through literature study.

Data analysis techniques applied descriptive-qualitative analysis techniques carried out intertwining with the data collection process. Qualitative-descriptive analysis is the process of arranging, sorting, grouping, coding, categorizing, interpreting, and interpretation of qualitative and quantitative informative data. The results of this analysis describe, illustrate the phenomenon that have been systematically, factually and accurately studied. 


\section{Result and Discussion}

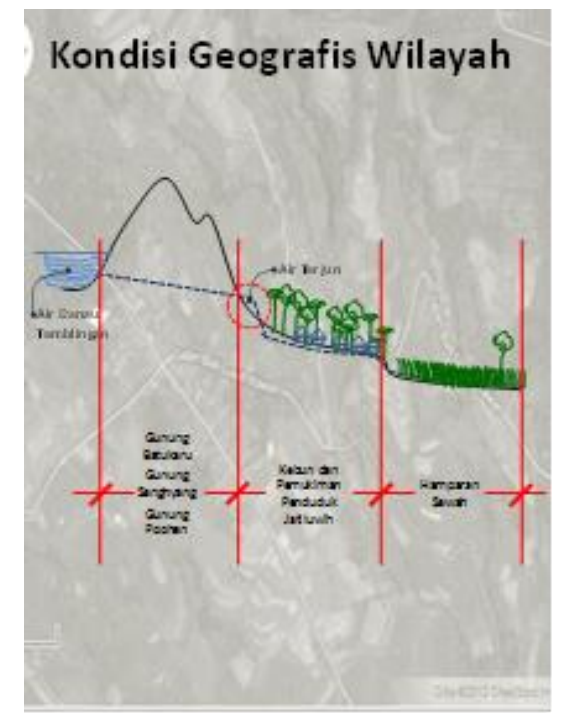

Fig. 2. Topographical Sketch of Jatiluwih Village. Source: Field Analysis collected from the result of interview with Regional Development Planning Board (Bappeda) of Tabanan and Public Figures of Jatiluwih, 2016.

Based on the geographical conditions of Banjar Gunungsari Desa area as shown in figure 2 (the results of interviews with several community leaders, 2016), it shows that the potential possessed by Banjar Gunungsari Desa area is a very prospective potential in terms of agricultural land use. What needs to be maintained is the change in agricultural functions to other functions. The concern of the residents of Banjar Gunungsari Desa towards the area of their village is the change of land function due to the government regulations and controls that are not strong. The order of traditional pattern of the area owned by Banjar Gunungsari Desa should be maintained as one of the attractions for tourists visiting this Banjar.

Since Jatiluwih was awarded as a World Cultural Heritage (WCH), the growth of tourist visits in this village has increased significantly. Field information with Jatiluwih Village community leader, I Nyoman Sweden (2016), stated that tourist visits after Jatiluwih area was enthroned as WCH increased threefold compared to 3000 tourist visits per month in 2011 (before being awarded $\mathrm{WCH}$ ) to 10,000 people/month after being awarded $\mathrm{WCH}$ ). Furthermore, Sweden conveyed that the funds gained from the tourist visits entering through the portal (ticket sales) before being awarded WCH were about 37-48 Million/month, while after being enthroned $\mathrm{WCH}$, it jumped up to 180 Million/month. The revenue growth from tourist visits provide great impacts to community activities and development in Jatiluwih Village in general and the Banjar Gunungsari Desa in particular.

Some people at Banjar Gunungsari Desa are concerned and afraid to see the tourism development in their village. Reality in the field shows that the development of tourism in Jatiluwih area has not been in favor of Jatiluwih community. For example, rice fields and farmers Banjar Gunungsari Village are tourism assets sold for tourist satisfaction, but the 
infrastructure prepared is very minimum. Farmers remain poor while investors reap huge profits from this tourism activity. In fact, if there are no rice fields and farmers, tourism in Jatiluwih will not develop.

Some villa developments have breached the Regulation of Regent No. 9 of 2005 specifically article 14 paragraph (5) particularly violations against the sanctity radius of temple and the face of buildings that are very in contrast to the environment. The development of tourism facilities prioritizes economic interests than the preservation of nature and culture. This means that sustainable tourism development is only a jargon and not realized in Jatiluwih area. This development is worried by the residents of Banjar Gunungsari Desa.

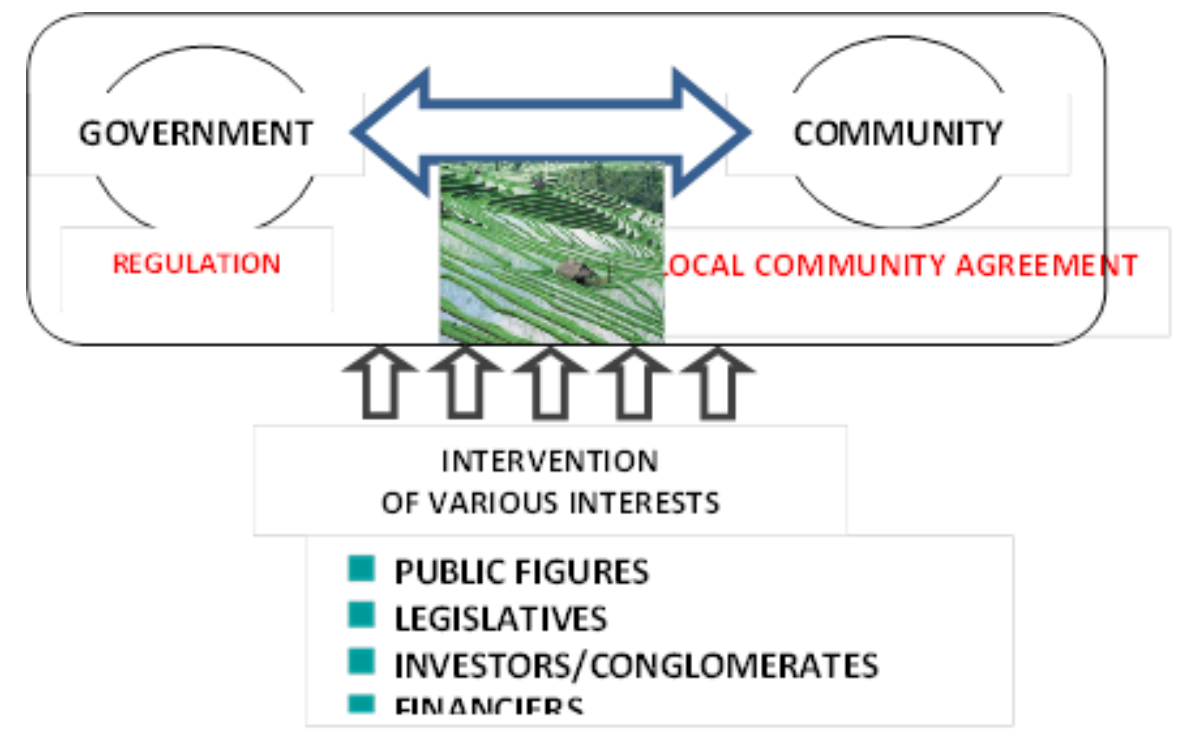

Fig. 3. The Challenge of Natural and Cultural Tourist Resort Development of Jatiluwih requires the power of local community agreement.

Source: Field Analysis (Parwata, 2016).

\subsection{Preservation of "hulu-teben" concept in the territory of banjar gunung sari desa}

For people of Banjar Gunungsari Desa, the belief in the concept of hulu-teben (topbottom) is still believed to be a hierarchical concept in structuring housing and its environment. So, the community hopes that the existing Hulu-Teben space structure will be maintained and preserved. The community leader of Banjar Gunungsari Desa, I Nyoman Sugita (Guru Londo), 2014 hoped that the existing spatial pattern of Banjar should be maintained and become a tourist attraction, as in Penglipuran Village in Bangli. Since, in addition to the hierarchy of space, the layout of holy places, residences and grave yards that have existed for a long time, in the upper reaches of Gunungsari Desa, there are 3 waterfalls namely, Yeh Gembrong waterfall, Giri Kusuma Waterfall, and Umakayu Waterfall. These three waterfalls are one of the tourist attractions that can be developed. The direction to this 
waterfall crosses residential settlements and rice fields, so tourists can immediately see residents' homes and at once have recreation in the waterfall.

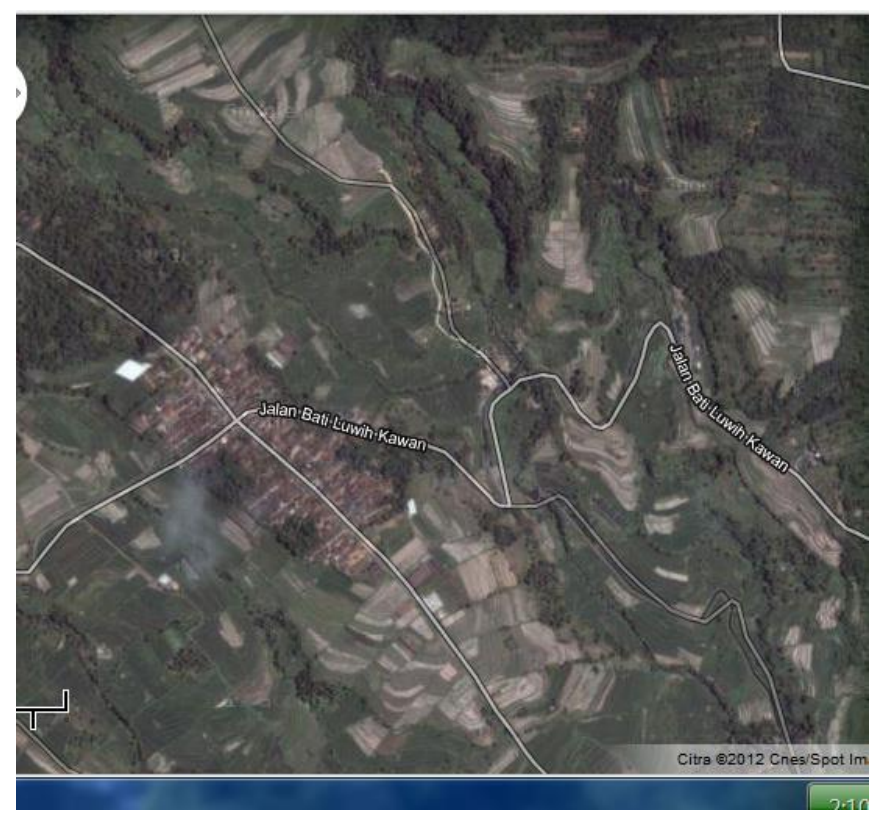

Figure 4. Hulu-Teben Position of Banjar Gunungsari Desa, Jatiluwih Village, Penebel-Tabanan.

Source: Satelite Image and Field Observation (2014).

Other potential that must be considered in spatial arrangement planning at Banjar Gunungsari Desa, according to I Gede Sweden (Guru Mari), 2016 is that there are 11 water springs at Banjar Gunungsari Desa, among others:

a. Hulu (upper): 1) Giri Kusuma South water spring; 2) Giri Kusuma water spring; and 3) Suranadi water spring;

b. Middle: 1) Yeh Gembrong water spring; 2) Samping Yeh Gembrong water spring; 3) Tuwuran Kauh water spring; 4) Beji Bedugul Umakayu water spring; 5) Beji Taman Sari water spring;

c. Teben (lower: 1) Bat Gedong water spring; 2) Yeh Lis water spring; 3) Yeh Saab water spring;

All those water springs are the water sources for irrigation of the existing subaks in Jatiluwih Village area. The Subaks in Jatiluwih Village area which remain potential, are (Heru K. Tardjoto, 2014): 1) Subak Umakayu: in an area of 38 HA, 75 famers, 415 people; 2) Subak Gunugsari: in an area of $45 \mathrm{Ha}, 83$ farmers, 375 people; 3) Subak Jatiluwih: in an are of 90 Ha, 319 farmers, 1595 people; 4) Subak Besikalung: in an area of $40 \mathrm{Ha}, 86$ farmers, 430 
people; 5) Subak Kesambi: in an area of $25 \mathrm{Ha}, 30$ farmers, 150 people; and Subak Kedamaian: in an area of $65 \mathrm{Ha}, 56$ farmers, 280 people.

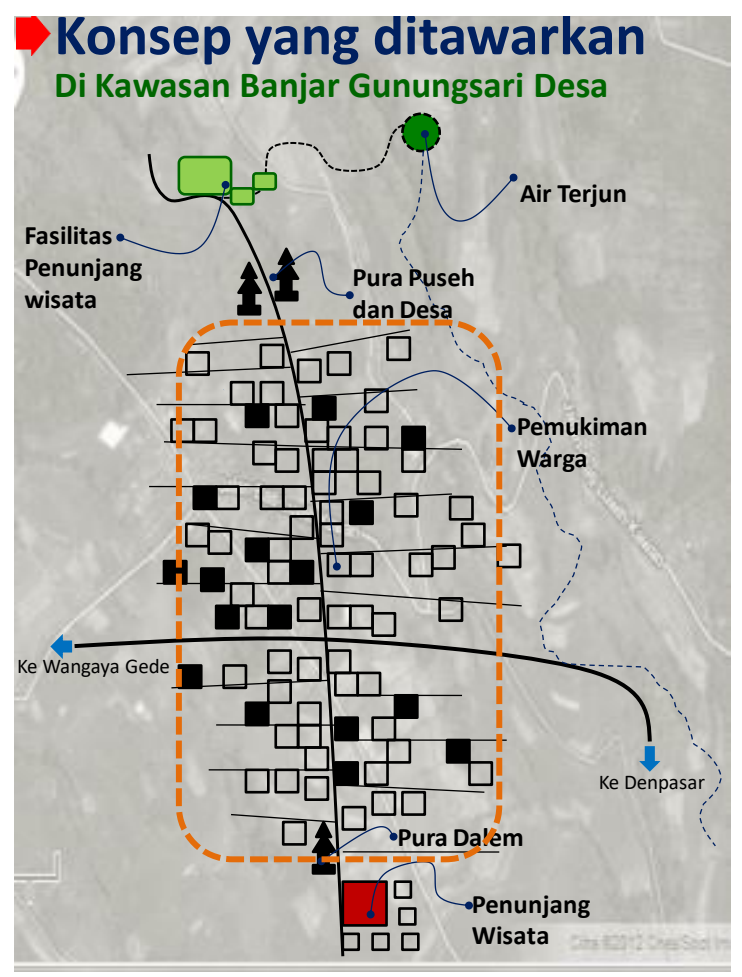

Figure 5. The concept offered in the effort to maintain spatial arrangement of Hulu-Teben. Source: Field Analysis (2015).

\subsection{Community Based-Development Model of Tourist Village at Banjar Gunungsari Desa}

The concept of hulu-teben owned by Banjar Gunungsari Desa provides strength of hope that this concept can be maintained along with the development of tourism entering the region. The expectations of the people of Banjar Gunungsari Desa, particularly the Banjar community and Jatiluwih Village community in general in developing tourism village based on natural potential are:

1) The development of Banjar Gunungsari Desa area as a tourism village must be guided by the philosophy of Tri Hita Karana. Tri Hita Karana is a philosophy of life based on Hinduism teaching the importance of harmonious relations between humans and God (parhyangan), amongst humans (pawongan), and with the natural environment (palemahan) to achieve inner and outer welfare; 
2) The application of the concept of Tri Hita Karana in the spatial arrangement of Banjar area is realized by maintaining the concept of Hulu-Teben spatial plan at Banjar Gunungsari village Desa area today;

3) The residents of Banjar Gunungsari Desa must be involved in the planning, implementation, supervision of the development and development of tourism village in a sustainable manner. This development is of course without removing the natural topographic hierarchy of the banjar region;

4) The appreciation and respect to the rights of local communities, namely by sharing income generated from the tourism process, safeguarding the sanctified area, involvement of the socio-cultural aspects of the community owned, and maintaining the survival of the local community;

5) The use of housing as tourist accommodation, not establishing new accommodations that tend to damage the layout of the village;

6) The increase use of water sources, especially waterfalls at Banjar Gunungsari Desa area as sacred attractions;

7) The increase of autonomous and independent institutions formed by local communities to safeguard customs and culture at Banjar Gunungsari Desa;

8) Paying attention to environmental sustainability, both sacred and profane environment;

9) The expectation of Banjar Gunungsari Desa community to the development in Jatiluwih Village, is that the government should facilitate physical planning of public buildings, village infrastructure, improvement of tourism supporting facilities, development of arts and culture and preservation of subak system and irrigation infrastructure. From the management aspect, the community should be more involved because it is directly involved in the area.

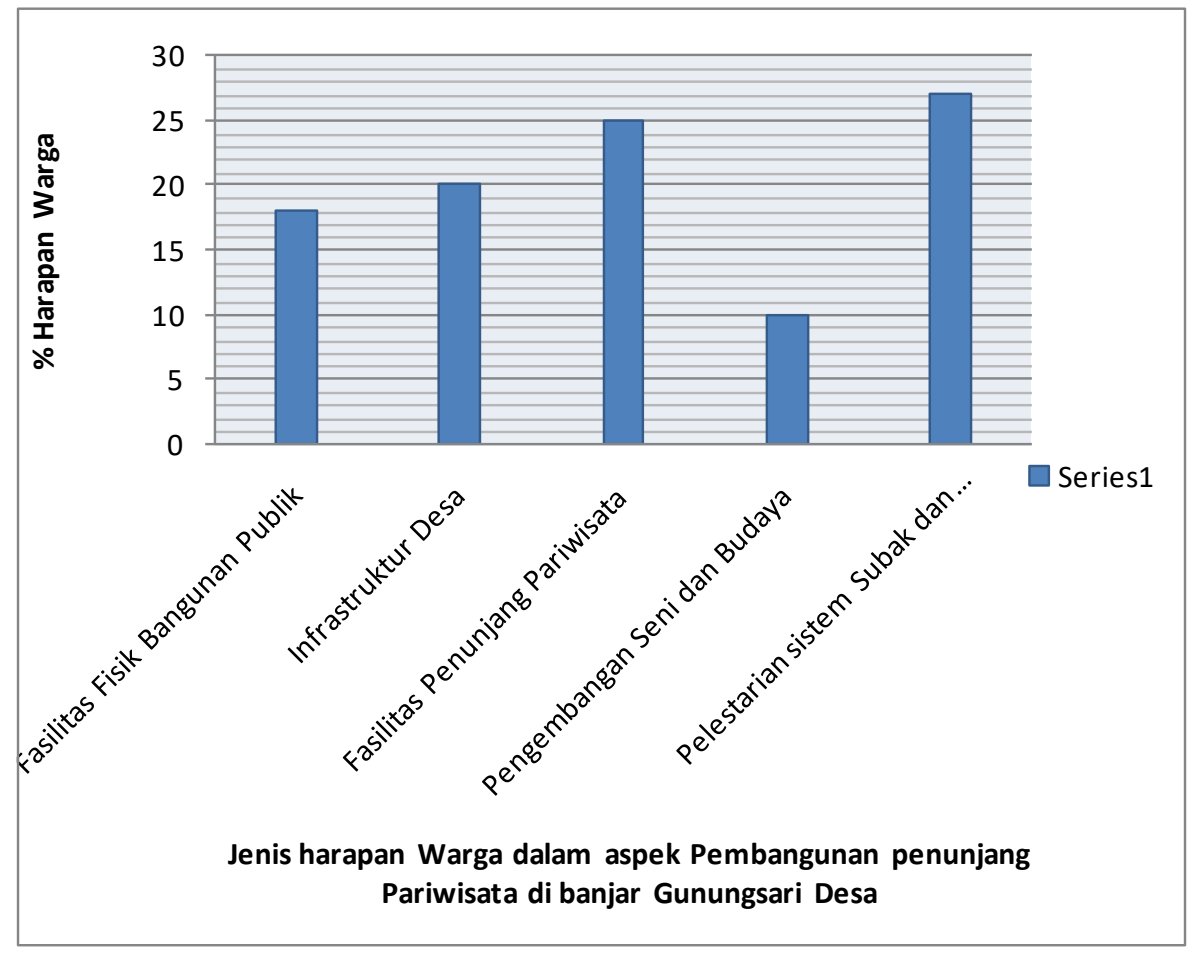




\section{Conclusion}

It is necessary to involve local residents, especially residents of Gunungsari Desa, in the planning, implementation and supervision of the development process in order to maintain the Hulu-Teben spatial planning concept and improve tourism management in Jatiluwih Village.

The Public Figures of Banjar Gunungsari Desa hope that the government will pay attention to the development plans in this village. By using a questionnaire on the community expectations in development planning, it can be described as follows: 1) the residents' needs for the physical planning of public building facilities $(18 \%) ; 2)$ village infrastructure $(20 \%) ; 3)$ Tourism supporting facilities $(25 \%) ; 4)$ art and cultural development $(10 \%)$ and preservation of subak system and irrigation infrastructure (27\%). From the management aspect: the participation of residents involved in management (60\%) and the government $(40 \%)$.

Residents and leaders of Banjar Gunungsari Desa community are prepared to maintain the results of the development carried out in Jatiluwih Village area. So far, the community has been accustomed to carry out what was ordered by the government without participating in the development.

\section{References}

[1] Bahua, I.M.: Participative Planning Method in the Development. downloaded from internet on 14 February 2015 (2011)

[2] Huraerah, A.: Community Organizing and Development. Humaniora, Bandung (2008)

[3] Inskeep, E.: Tourism Planning, and Integrated and Sustainable Development Approach. Van Nostrand Reinhold, New York (1991)

[4] Nuryanti, W.: Heritage, Tourism and Local Communities. UGM Press, Yogyakarta (1999)

[5] Suarnatha, I M.: Echo-Tourism Planning, the Material was presented in the Seminar of IAI Bali, Denpasar ( 2012)

[6] Urmila D.: Local Community Participative Based- Tourist Village Development in Jatiluwih Tourism Village, Tabanan, Bali. Kawistara. Vol. 3. pp. : 117-226 (2013)

[7] Pearce, D.: Tourism a Community Approach. 2nd ed. Harlow Longman (1995)

[8] Wearing, S.L., \& Donald, Mc.: The Development of Community Based Tourism: Re-Thinking the Relationship between Tour Operators and Development Agents as intermediaries in rural and isolated area Communities. Journal of Sustainable Tourism (2001)

[9] Wesnawa.: Tri Hita Karana. Babad Bali, article (2010)

[10] I Nyoman Sweden (Guru Mari); I Nyoman Sugita (Guru Londo); Heru K. Tardjoto and Grace Tardjoto: Depht Interview (2014) 